\title{
JNPH
}

Volume 6 No. 1 (April 2018)

(C) The Author(s) 2018

\section{HUBUNGAN KEBIASAAN LAMA DUDUK TERHADAP PROSES TERBENTUKNYA KRISTAL URIN PADA PENJAHIT DI WILAYAH KOTA BENGKULU}

\section{RELATIONSHIP OF OLD HISTORY TO THE PROCESS OF THE URINE CRYSTAL FOR THE SEWER IN THE BENGKULU CITY REGION}

\author{
JON FARIZAL \\ POLITEKNIK KESEHATAN KEMENKES BENGKULU \\ Email : jonfarizal77@gmail.com
}

\begin{abstract}
ABSTRAK
Latar Belakang : Kristal urin merupakan kondisi dimana terbentuknya batu di saluran keluarnya urin dapat berada di ginjal, ureter, kandung kemih maupun uretra. Kejadian batu saluran kemih (BSK) lebih banyak terjadi pada orang-orang yang banyak duduk dalam melakukan pekerjaannya seperti pekerja konveksi (penjahit), karena mengganggu proses metabolisme tubuh serta akan mengakibatkan kalsium tulang lepas kedarah, selanjutnya akan memacu pembentukan kristal urin yang akan mengakibatkan timbulnya batu saluran kemih. Tujuan penelitian ini adalah untuk mengetahui adakah hubungan antara kebiasaan lama duduk terhadap proses terbentuknya kristal urin pada penjahit di wilayah kota BengkuluMetode : Menggunakan desain cross sectional dengan sampel 30 responden. Urin pagi responden diperiksa secara mikroskopis dilihat ada atau tidaknya kristal urin yang ditemukan. Kemudian data dianalisis dengan menggunakan korelasi spearman.Hasil : Kebiasaan lama duduk pada penjahit di wilayah kota bengkulu tahun 2017 dengan sampel sebanyak 30 sampel diketahui rerata kebiasaan lama duduk penjahit mean adalah 8 jam dan dengan median nilai tengah 7,94 jam , nilai minimum 7 jam dan nilai maksimum 10 jam. Hasil statistik dengan menggunakan uji spearman didapatkan hasil $\mathrm{p}=0,10(\mathrm{p}>0,05)$ sehingga tidak ada hubungan antara kebiasaan lama duduk dengan proses terbentuknya kristal urin pada penjahit diwilayah kota BengkuluKesimpulan : Tidak ada hubungan antara kebiasaan lama duduk terhadap proses terbentuknya kristal urin pada penjahit di wilayah kota Bengkulu
\end{abstract}

Kata kunci : Kristal urin, penjahit.

\begin{abstract}
Background: Urine crystals are conditions in which the formation of stones in the outlet of the urine can be in the kidneys, ureters, bladder and urethra. The incidence of urinary tract stones (BSK) is more prevalent in people who sit in many jobs such as convection workers (tailors), because it interferes with the body's metabolism process and will cause bone loss calcium bleeding, will further spur the formation of urine crystals that will lead to the emergence of urinary tract stones. The purpose of this study is to know whether there is a relationship between the old habit of sitting on the process of formation of urine crystals at tailors in the city of Bengkulu Method: Using a cross sectional design with a sample of 30 respondents. The morning urine of the respondent is examined microscopically by the presence or absence of urine crystals found. Then the data is analyzed by using spearman correlation. Result: Long
\end{abstract}


habits seated at tailors in bengkulu city area in 2017 with a sample of 30 samples known mean habits of seats sat tail mean is 8 hours and with median value of 7.94 hours, a minimum value of 7 hours and a maximum value of 10 hours. The result of statistic by using spearman test result $p=0,10(p>0,05)$ so there is no relation between old habit of sitting with process of urine crystals forming at tailor in city region Bengkulu Conclusion: There is no relation between old habit of sitting to process of crystal formation urine on tailors in the city area of Bengkulu

\section{Keywords: Crystal urine, tailor.}

\section{PENDAHULUAN}

Batu saluran kemih yang disingkat BSK adalah terbentuknya batu yang disebabkan oleh pengendapan substansi yang terdapat dalam air kemih yang jumlahnya berlebihan atau karena faktor lain yang mempengaruhi daya larut substansi (Lina 2008). Pembentukan batu saluran kemih (BSK) ada hubungannya gangguan aliran urin, gangguan metabolik, infeksi saluran kemih, dehidrasi dan keadaan lain (Sulistyowati Retno 2013).

Penyakit batu saluran kemih (BSK) pada saat sekarang ini memang telah menjadi masalah kesehatan di dunia. Penyakit batu saluran kemih ini merupakan penyakit ketiga terbanyak dibidang urologi setelah penyakit infeksi dan penyakit kelenjar prostat. Di negara-negara barat $5-10 \%$ penduduknya suatu saat dalam hidupnya pernah menderita penyakit ini dengan insidensi sekitar $0,14 \%$ per tahun dari jumlah penduduk (Muslim 2007).

\section{Menurut National Kidney Foundation} (NKF) 26 juta orang dewasa di Amerika menderita penyakit ginjal. Pada tahun 2013 47.000 orang meninggal karena penyakit batu ginjal. Berdasarkan data dari (Riskesdas,2013) menunjukkan bahwa secara nasional $0,2 \%$ penduduk hi Kristal urin merupakan kondisi dimana terbentuknya kristal disaluran kemih yang dikeluarkan melalui urin, yang apabila berlangsung lama dan menumpuk akan menjadi batu saluran kemih. Pembentukan kristal berkaitan dengan konsentrasi berbagai garam di urin yang berhubungan dengan metabolisme makanan dan asupan cairan serta dampak dari perubahan yang terjadi dalam urin seperti perubahan $\mathrm{pH}$ dan suhu, yang mengubah kelarutan garam dalam air seni dalam menghasilkan pembentukan kristal (Soemarko 2012).

Pada penelitian sebelumnya yang dilakukan oleh Rifki Muslim orang-orang yang pekerjaannya banyak duduk dan kurang bergerak lebih sering atau faktor terkena penyakit batu saluran kemih lebih besar dari pada orang dengan pekerjaan yang banyak gerak atau kerja fisik. Penelitian lain juga pada angkatan laut Inggris diketahui para perwira yang banyak duduk dikantor lebih sering terkena batu saluran kencing dibanding para prajurit yang banyak melakukan latihan atau kerja fisik. Dan penelitian satunya lagi ditemukan penderita batu saluran kemih lebih banyak pada pegawai kantor dan manajer dibanding pekerja kasar (Muslim 2007).

Dalam hal ini pekerja yang akan dijadikan responden pada penelitian yang akan dilakukan adalah berprofesi sebagai penjahit yang aktifitasnya setiap hari duduk dalam waktu yang cukup lama saat bekerja. Sehigga perlu dilakukan pemeriksaan mikroskopis pada urin penjahit untuk mengetahui adanya hubungan antara kebiasaan lama duduk pada penjahit agar mengetahui kemungkinan telah terbentuknya batu saluran kemih (BSK) pada penjahit.

\section{METODE PENELITIAN}

Metode penelitian yang dilakukan dengan cara survey analitik dengan pendekatan cross sectional yaitu untuk mempelajari korelasi antara kebiasaan lama duduk dan pengukuran kristal urin yang dilakukan pada waktu yang bersamaan. Pengambilan sampel juga menggunakan lembar observasi yang disertai dengan pengambilan sampel urin pagi responden. Lembar observasi terdiri dari pertanyaan- 
pertanyaan kriteria inklusi dan kriteria ekslusi penjahit yang akan dijadikan responden. Penelitian dilakukan di Laboratorum Terpadu Poltekkes Kemenkes Bengkulu. Tehnik pengambilan sampel pada penelitian ini menggunakan tehnik simple random sampling sehingga seluruh penjahit yang masuk kedalam kriteria inklusi diambil secara acak dengan perhitungan jumlah sampel yang dibutuhkan yaitu sebanyak 30 sampel.

\section{HASIL PENELITIAN}

Hasil analisis penelitian hubungan kebiasaan lama duduk terhadap proses terbentuknya kristal urin pada penjahit di wilayah kota Bengkulu

Tabel 1 Hasil analisis Kebiasaan Lama Duduk pada Penjahit di Wilayah kota Bengkulu

\begin{tabular}{cccccc}
\hline Variabel & $\mathrm{N}$ & Mean & Median Nilai Min & $\begin{array}{c}\text { Nilai } \\
\text { Max }\end{array}$ \\
\hline $\begin{array}{c}\text { Lama } \\
\text { duduk }\end{array}$ & 30 & 8,00 & 7,94 & 7 & 10 \\
\hline
\end{tabular}

Tabel 1 diketahui rerata kebiasaan lama duduk penjahit adalah 8,00 jam dan dengan nilai tengah 7,94 jam, nilai minimum 7 jam dan nilai maksimum 10 jam.

Tabel 2 Hasil analisis pada Kristalisasi Urin terhadap Penjahit di Wilayah kota Bengkulu

\begin{tabular}{ccc}
\hline Kristalisasi urin & $\mathrm{N}$ & Persentase $\%$ \\
\hline Negatif & 26 & $86,6 \%$ \\
\hline Positif & 4 & $13,4 \%$ \\
\hline Total & 30 & $100 \%$ \\
\hline
\end{tabular}

Tabel 2 diketahui bahwa hampir seluruh penjahit $(86,6 \%)$ tidak mengalami terbentuknya kristal urin. Sedangkan hanya sebagian kecil saja penjahit yang mengalami proses terbentuknya kristal urin $(13,4)$.

\section{a. Analisis Bivariat}

Analisis bivariat dilakukan untuk melihat adakah hubungan kebiasaan lama duduk terhadap proses terbentuknya kristal urin pada penjahit di wilayah kota Bengkulu. Untuk melihat pengaruh kebiasaan lama duduk terhadap proses terbentuknya kristal urin digunakan uji korelasi spearman. Uji korelasi spearman yaitu uji yang digunakan untuk mengetahui kekuatan hubungan antara variabel independent (kebiasaan lama duduk) dengan variabel dependent (kristal urin)

Tabel 3 Hasil analisis uji Spearman Kebiasaan Lama Duduk Terhadap Proses Terbentuknya Kristal Urin pada Penjahit di Wilayah kota Bengkulu

\begin{tabular}{ccc}
\hline & & Kebiasaan Lama Duduk \\
\hline \multirow{3}{*}{ Kristal Urin } & $r$ & 0,464 \\
& $p$ & 0,010 \\
& $n$ & 30 \\
\hline
\end{tabular}

Tabel 3 diketahui nilai $(p=0,010)$ dibawah nilai $\mathrm{p}>0,05$ yang menunjukkan bahwa tidak terdapat korelasi yang bermakna antara dua variabel yaitu kebiasaan lama duduk dan pembentukan kristal urin. Nilai korelasi spearman 0,464 yang menunjukkan bahwa arah korelasi negatif dengan kekuatan korelasi yang sedang. Nilai korelasi negatif didapatkan dari arah korelasi yang berlawanan, semakinbesar nilai satu variabel, semakin kecil nilai variabel lainnya.

\section{PEMBAHASAN}

Hasil penelitian diketahui rerata kebiasaan lama duduk penjahit adalah 8,00 jam dan dengan nilai tengah 7,94 jam , nilai minimum 7 jam dan nilai maksimum 10 jam. Dengan jumlah responden sebanyak 30 responden.

Dari uji statistik kebiasaan lama duduk responden diperoleh nilai $(p>0,05)$ artinya tidak ada hubungan kebiasaan lama duduk terhadap proses terbentuknya kristal urin pada penjahit di wilayah kota Bengkulu. Hal ini terjadi karena para responden atau penjahit pekerja sudah dapat melakukan tindakan 
preventif yang baik ketika sedang bekerja, penjahit tidak terlalu banyak kehilangan cairan, oleh karena itu urinnya pun tidak menjadi hipersaturasi sehingga pembentukan kristal urin jarang terjadi, untuk mencegah terbentuknya kristal urin pada responden atau penjahit, mereka mengantisipasinya dengan cara meminum cairan sebanyak mungkin selama bekerja. Rata-rata setiap penjahit dalam sehari bisa mengahabiskan $>2500 \mathrm{~mL}$ air putih setiap harinya. (Maslachah 2009).

Penjahit yang terlalu banyak duduk maka kalsium tulang akan lepas ke darah, selanjutnya hiperkalsemia akan memacu timbulnya batu saluran kemih. Karena adanya supersaturasi kristal dalam air kemih. Kenaikan konsentrasi bahan pembentuk batu di dalam tubulus renalis akan mengubah zona stabil saturasi rendah menjadi zona supersaturasi metastabil dan bila konsentrasinya makin tinggi menjadi zona supersaturasi tinggi. Didalam air kemih terdapat protein yang berasal dari pemecahan mitokondria sel tubulus renalis yang berbentuk anyaman seperti sarang laba-laba. Kristal batu kalsium oksalat maupun kalsium posfat akan menempel pada anyaman tersebut dan berada di sela-sela anyaman sehingga terbentuk batu. (Lina 2008).

Jenis kristal yang didapatkan pada penelitian adalah kristal kalsium oksalat. Kaslium oksalat merupakan senyawa yang sukar larut dalam air dapat dihasilkan akibat terhambatnya pengeluaran urin. Hal tersebut dilakukan dengan cara supersaturasi urin. Supersaturasi urin merupakan adanya kelebihan suatu bahan dalam urin hingga melebihi batas kelarutan dalam urin, bahanbahan tersebut adalah kalsium oksalat. Dalam konsenterasi tinggi, terutama jika ditambah dengan pengurangan volume urin, memudahkan terjadinya kristalisasi. Faktor yang mempengaruhi terjadinya supersaturasi adalah pH urin. Sedangkan Kristal kalsium oksalat, yang mempengaruhi adalah rendahnya $\mathrm{pH}$ urin, volume urin berkurang . (Hawariy and Rodjani 2013).

Penelitian serupa telah dilakukan oleh Abdul Ghofur dengan judul "Pengaruh Lama
Kerja Terhadap Gambaran Kristalisasi Urin Pada Pekerja Konveksi di Desa Jajarwayang Kecamatan Bojong Kabupaten pekalongan, Jawa Tengah, 2013". Hasil penelitian menujukkan hasil positif pada sampel urin dengan lama kerja $\geq 3$ tahun sebesar $81 \%$ dan $19 \%$ menunjukkan hasil negatif. Sedangkan pada sampel urin $<3$ tahun $50 \%$ positif $1-2$ dan $50 \%$ negatif. Hasil uji statistik menunjukan terdapat pengaruh yang bermakna antara lama kerja pekerja konveksi terhadap gambaran kristal urin.

Pada penelitian yang telah dilakukan didapatkan hasil bahwa tidak ada hubungan antara kebiasaan lama duduk dengan proses terbentuknya kristal urin pada penjahit di wilayah kota Bengkulu tahun 2017 sehingga penelitian yang telah dilakukan ini tidak sejalan dengan penelitian yang telah dilakukan sebelumnya.

\section{KESIMPULAN}

Rerata kebiasaan lama duduk penjahit diperoleh mean $(8,00$ jam $)$ median (7,94 jam), nilai minimum 7 jam dan maksimum 10 jam.

Dari 30 sampel yang diteliti hampir seluruh penjahit tidak ditemukan kristal urin $(86,6 \%)$, dan hanya sebagian kecil saja penjahit yang ditemukan kristal urin $(13,4 \%)$.

Tidak ada hubungan antara kebiasaan lama duduk dengan proses terbentuknya kristal urin pada penjahit diwilayah kota Bengkulu tahun 2017.

\section{SARAN}

1. Bagi institusi terkait sebagai tambahan referensi karya tulis ilmiah mengenai hubungan kebiasaan duduk lama terhadap proses terbentuknya kristal urin pada penjahit di wilayah kota Bengkulu.

2. Bagi pekerja agar pekerja selalu memperhatikan kedisiplinan dalam mengkonsumsi air minum atau cairan selama bekerja setiap harinya dengan cara mengkonsumsi air minum sedikitnya 4-10 Liter. Lakukan peregangan tubuh di selasela waktu bekerja serta usahakan tidak 
menahan buang air kecil.

3. Bagi peneliti lain selanjutnya bisa melakukan penelitian lebih lanjut mengenai faktor lain yang mempengaruhi terbentuknya kristal pada urin seperti makanan atau minuman yang dapat menyebabkan terbentuknya kristal urin atau bisa melanjutkan penelitian seperti ini dengan responden yang berbeda misalnya supir bus yang juga memiliki kebiasaan duduk lama.

\section{DAFTAR PUSTAKA}

Abdul Ghofur. 2007. "Pengaruh Lama Kerja Terhadap Gambaran Kristalisasi Urin Pada Pekerja Konveksi Di Desa Jajarwayang Kecamatan Bojong Kabupaten Pekalongan.”

Gandasoebrata. 2007. Penuntun Laboratorium Klinik. Jakarta: Dian Rakyat.

Hawariy, Salik, and Arry Rodjani. 2013. "Pengaruh Kadar Asam Urat Terhadap Kejadian Batu Asam Urat Pada Pasien Batu Saluran Kemih."

Indrawati, Nova. 2013. "Universitas Indonesia Asuhan Keperawatan Pada Tn . I Dengan Batu Saluran Kemih Di Lantai 5 Bedah."

Izhar M. Dody, Haripurnomo, Darmoatmodjo. 2007. "Hubungan Antara Kesadahan Air Minum, Kadar Kalsium Dan Sedimen Kalsium Oksalat Urin." $F K$ UGM 23 (4).

Lina, Nur. 2008. "Faktor-Faktor Risiko Kejadian Batu Saluran Kemih Pada Laki-Laki (Studi Kasus Di RS Dr. Kariadi, RS Roemani Dan RSI Sultan Agung Semarang)." Jurnal Article.

Maslachah, Siti Chairul. 2009. "Pengaruh Tekanan Panas Terhadap Pembentukan Kristal Urin Pekerja Pada Pabrik Tahu Di Kecamatan Polokarto Sukoharjo." Universitas Sebelas Maret.

Muslim, Rifki. 2007. "BSK-Problema Gaya Hidup." Universitas Diponegoro Semarang. Semarang: Badan Penerbit Universitas.
Notoatmodjo, Soekidjo. 2010. Metodologi Penelitian Kesehatan Cetakan Kedua. Jakarta: PT. Rineka Cipta.

Riskesdas. 2013. "Riset Kesehatan Dasar." Kementrian Kesehatan RI.

Soemarko, Dewi Sumaryani. 2012. "Pengaruh Lingkungan Kerja Panas Terhadap Kristalisasi Asam Urat Urin Pada Pekerja Di Binatu, Dapur Utama, Dan Restoran Hotel X [Tesis]." Depok: Universitas Indonesia, no. 136: 38-42.

Sulistyowati Retno, Onny Setiani dan Nurjazuli. 2013. "Faktor Risiko Yang Berhubungan Dengan Kejadian Kristal Batu Saluran Kemihdi Desa Mrisi Kecamatan Tanggungharjo Kabupaten Grobogan Risk Factors Related to the Occurrence of Urinary Calculus among Inhabitants at Mrisi." Jurnal Sehatan Lingkungan Indoesia 12 (2): 99-105.

Syaifuddin. 2009. Fisiologi Tubuh Manusia Untuk Mahasiswa Keperawatan,. Jakarta : ECG. 